\title{
Higher Education Development and Regional Differences in China
}

\author{
Lili Wang \\ Business School, Shandong Jianzhu University, Jinan, CHINA \\ Wenwen Xiao \\ School of Management, Shandong University, Jinan, CHINA
}

Received 27 June 2017 • Revised 2 September 2017 • Accepted 25 September 2017

\begin{abstract}
This paper analyzed the development of higher education and the regional differences in China, using the survey data and official statistics. Two indicators, the undergraduate students of per 100,000 population and higher education's contribution to GDP growth, were applied respectively to study the regional differences. The results showed that higher education in China was enjoying great development, fundamentally constructed talent cultivation system and comprehensively reasonable resource distribution. However, some colleges and universities still had some problems, such as incorrect orientation, overheated scale expansion and insufficient capital investment. Besides, higher education in China was suffering from considerable regional differences, namely higher education in East China is developing rapidly and contributing more to the economic growth, while the West China has presented slower rate of higher education development and smaller contribution to economic growth. Based on the problems lying in present reality of higher education development, this paper proposed the suggestions to enhance the development of higher education in China and to dispel the regional differences in higher education performance.
\end{abstract}

Keywords: higher education, regional differences, higher education quality

\section{INTRODUCTION}

With the advent of knowledge economy era, building an innovative country and enhancing national competitiveness become China's important strategic decisions in the context of adjustment of industrial structure and transformation of economic development pattern (Fang,2012; Ding,2015; Chen et al., 2017; Ekici et al., 2017; Gao et al., 2017). To build an innovative country, science and technology are the key, qualified personnel are the core, and education is the foundation. The training and growth of qualified personnel are inseparable from higher education. Higher education is the highest level of academic education before employment, main channel to enhance knowledge and ability, and an important component of China's education system. Making great efforts to develop higher education oriented to enterprise management, professional skills, high skills and social work personnel is an important part of the construction of qualified personnel, an important measure to build an innovative country and improve national competitiveness (Mok,2016; Huang,2017; Farhan \& Aslam, 2017). By improving the management system and mechanism of higher education, improving qualified personnel training system, strengthening informatization construction, innovating teaching methods and improving service capabilities to make contributions to the construction of learning society and meet people's multi-level and diversified needs.

(C) Authors. Terms and conditions of Creative Commons Attribution 4.0 International (CC BY 4.0) apply. Correspondence: Lili Wang, Business School, Shandong Jianzhu University, Jinan, China. 


\section{Contribution of this paper to the literature}

- Through the actual survey and official statistics, this paper analyzed the development and the main problems of higher education in China. The strategic layout of China's higher education has basically formed, but there is still much to be done for most universities to catch up with world-class universities.

- As for the regional differences of higher education in China, government should formulate a long-term plan to support the development of education in the western poverty-stricken areas, and set up the development of education in poverty-stricken areas fund.

- Government should strengthen education counterpart support efforts, increase the investment of the central government, and mobilize all social forces to develop the education business in China.

Chinese higher education has developed rapidly since 1990, and the number of colleges and universities has increased enormously (Hu, 2013; Gupta, 2015). In 1990, there were 1075 general institutes of higher education, and the number grew for 2560 in 2015 . The gross enrollment rate also continues to rise, the rate of higher education reached 40\%in 2015, and China will step into a stage of universal higher education. In the process of persistent and fast development of higher education, the acute problem of unbalanced development among different regions always exists. The development gap of regional higher education has become more and more serious recent years due to natural, historical, social, economic and other reasons, and it brings about directly the gap of regional personnel cultivating, finally it will become the key constraint of Chinese balanced economic development (Feng, 2013; Liu, 2016; Opitz et al., 2017). Therefore, the study on Chinese higher education development gap among different regions is significant to analyze the development status of Chinese higher education and development gap among different regions, it is also of great importance in making suggestions on the balanced higher education development among different regions.

This paper analyzed the development of higher education and the regional differences in China, using the survey data and official statistics. Two indicators, the undergraduate students of per 100,000 population and higher education's contribution to GDP growth, were applied respectively to study the regional differences. Based on the problems lying in present reality of higher education development, this paper proposed the suggestions to enhance the development of higher education in China and to dispel the regional differences in higher education performance.

\section{DATA SOURCES}

\section{Survey Data}

In this paper, combining the official data published by colleges, and referring to the data published by the Ministry of Education, the Ministry of Human Resources and Social Security and other relevant ministries, typical colleges were selected for research. Through field research, field interviews and questionnaires, the present situation and problems of China's higher education were discussed in the aspects of orientation of running college, training of qualified personnel and mode of running college. The information was collected from 553 colleges in North China, South China, East China, Northwest China, Southwest China, Central China and Northeast China. Among them, the number of effective samples of subordinate colleges, provincial colleges, municipal colleges and private colleges were: $84,366,53$ and 50, respectively, among which, provincial colleges had the largest effective sample number, making up $66 \%$. The number of recovered colleges in the seven areas was 63, 124, 204, 30, 55, 43, and 34, respectively. After the survey data were collected, a basic verification of the survey data was conducted. The basic verification referred to the evaluation of quality of the survey data from the aspects of standardization, correlation, accuracy and reliability, which can ensure the quality of basic data and lay a scientific basis for the objective analysis and observations of research report. Correlation, accuracy and reliability verification were the basis to reflect the representativeness and authenticity of survey samples, and the foundation for the objective reflection of this report, which were illustrated using Table 1 as an example. 
Table 1. Sample proof

\begin{tabular}{ccccccccc}
\hline & $\begin{array}{c}\text { North } \\
\text { China }\end{array}$ & $\begin{array}{c}\text { south } \\
\text { China }\end{array}$ & $\begin{array}{c}\text { East } \\
\text { China }\end{array}$ & $\begin{array}{c}\text { Northwest } \\
\text { China }\end{array}$ & $\begin{array}{c}\text { Southwest } \\
\text { China }\end{array}$ & $\begin{array}{c}\text { Central } \\
\text { China }\end{array}$ & $\begin{array}{c}\text { Northeast } \\
\text { China }\end{array}$ & Total \\
\hline Subordinate colleges & 23 & 7 & 21 & 8 & 9 & 12 & 4 & 84 \\
\hline Provincial colleges & 34 & 82 & 150 & 21 & 43 & 25 & 11 & 366 \\
\hline Municipal colleges & 3 & 18 & 14 & 1 & 0 & 5 & 12 & 53 \\
\hline Private colleges & 3 & 17 & 19 & 0 & 3 & 1 & 7 & 50 \\
\hline Total & 63 & 124 & 204 & 30 & 55 & 43 & 34 & 553 \\
\hline
\end{tabular}

In this paper, after the survey data of different colleges were collated, they were counted, analyzed and evaluated objectively "with the investigation as the basis, data as the foundation, research as the core, and goal as the guidance". The survey data were collated according to the overall target and survey plan, and the indicators were designed according to research needs and processed into statistical data, including the classification system, quantification standard and data extraction principle of design statistics items, which guaranteed the unity of sampled data and the normalization of statistical data.

\section{Official Statistics}

This paper uses gross domestic product (GDP) to measure economic growth. To eliminate the sharp fluctuations in GDP caused by price factors, the annual GDP is calculated as the comparable price of 1990. The data are from the gross domestic product of all regions in the China statistical yearbook (2000-2016).

In this paper, the investment of education is used to measure the investment of education. The data are all from the financial statistics yearbook of China (2000-2016).

\section{DEVELOMENT STATUS OF HIGHER EDUCATION IN CHINA}

According to survey data, the strategic layout of China's higher education has basically formed. On the basis of setting up the systematic knowledge system, China's colleges actively dock the needs of society, and have initially formed the teaching mode of serving the national strategy and regional economic and social development. The formation of the strategic layout of higher education mainly consists of the formation of the diversification of college running subjects of higher education, reasonable allocation of resources and sound personnel training system.

\section{Diversity of Investment and School - Running Mode}

In view of college running subjects, China's colleges can be divided into four types: subordinate colleges, provincial colleges, municipal colleges and private colleges. The number of provincial colleges is the largest, and subordinate colleges have the largest average number of students. This shows that subordinate colleges are still the main body of continuing education talent training among colleges. Although municipal colleges and private colleges have no advantages in the number of colleges and the average number of students, they are still an important part of China's higher education, and make important contributions to the popularization of China's higher education. In terms of student training, different colleges train their students at different levels according to different market needs. Subordinate colleges basically have a complete system for training junior college, undergraduate college and graduate college students, and municipal colleges and private colleges basically have a complete system for training junior college and undergraduate college students. On the whole, the personnel training structure of China' colleges is basically reasonable. Table $\mathbf{1}$ also shows that China's higher education has formed a structure where subordinate colleges, provincial colleges, municipal colleges and private colleges are college running subjects, and private colleges' participation in higher education shows that the diversification of the college running subjects of China's higher education has been basically formed. 
Table 2. School-enterprise cooperation statistics

\begin{tabular}{|c|c|c|c|c|c|}
\hline & & $\begin{array}{c}\text { Subordinate } \\
\text { colleges }\end{array}$ & $\begin{array}{c}\text { Provincial } \\
\text { colleges }\end{array}$ & $\begin{array}{c}\text { Municipal } \\
\text { colleges }\end{array}$ & $\begin{array}{l}\text { Private } \\
\text { colleges }\end{array}$ \\
\hline \multirow{5}{*}{$\begin{array}{l}\text { School-enterprise } \\
\text { cooperation } \\
\text { (sample size:127) }\end{array}$} & $\begin{array}{l}\text { Enterprise investment } \\
\text { assistance }\end{array}$ & 31 & 63 & 6 & 2 \\
\hline & Enterprise training base & 12 & 38 & 7 & 6 \\
\hline & Enterprise practice base & 33 & 52 & 11 & 4 \\
\hline & $\begin{array}{l}\text { Administration section for } \\
\text { cooperation }\end{array}$ & 3 & 6 & 2 & 1 \\
\hline & $\begin{array}{l}\text { Scientific institutions for } \\
\text { cooperation }\end{array}$ & 8 & 19 & 7 & 1 \\
\hline \multirow{2}{*}{$\begin{array}{l}\text { Serving the } \\
\text { enterprise (sample } \\
\text { size:64) }\end{array}$} & $\begin{array}{l}\text { Order - based cultivating } \\
\text { mode }\end{array}$ & 4 & 23 & 15 & 9 \\
\hline & $\begin{array}{l}\text { Solving problems for } \\
\text { enterprise }\end{array}$ & 16 & 21 & 14 & 7 \\
\hline
\end{tabular}

\section{Well - Organized Personnel Training System}

The popularization of higher education is a unification of quantity and quality, where "quantity" refers to $15 \%-50 \%$ enrollment rate of school-age young students, and "quality" refers to a series of changes, such as diversification of training objectives and education model, expansion of education function, change of educational philosophy, curriculum, teaching method, admission qualification, management mode and relationship between higher education and society. Judging from the development status of China's higher education, China's higher education has basically realized the unification of quantity and quality.

The positioning of personnel training of China' colleges is clear. The colleges carry out their personnel training from the two aspects of society and individuals, take the mission entrusted by the national educational undertakings as the core, and undertake the function of providing higher education for students. From a social perspective, it is a customized training formed to develop reserve personnel and to meet the development of country and enterprise. For example, some colleges focus on cadre education by actively carrying out the training of party and government personnel to train senior civil servants, senior scientific and technological personnel and academic backbone; some colleges actively serve China's western development strategy by supporting and encouraging the training of personnel in the western regions and increasing the intensity of the training of personnel in the western regions, making great contributions to the training of personnel in the western regions; some colleges actively participate in the "National Training Program" project by training backbone teachers for the national primary and secondary education.

According to statistical data, the colleges set up special personnel training programs, actively dock the needs of the state and society, actively serve the demands of enterprises' human resources, and develop "order form" training programs according to the development needs of enterprises. Take provincial colleges for example, they set up different majors, with an average of 92 majors. Th college-enterprise cooperation by the colleges with an increasing number can serve the enterprises better, for example, the colleges developing college-enterprise cooperation make up $47 \%$, and the colleges undertaking social services make up $12 \%$. The colleges actively explore the college-enterprise cooperation characteristic modes, such as investment in financing college students by the enterprises, setting up enterprise training base and practice base as well as cooperative scientific research institutions to train application-oriented personnel for the enterprises. According to statistical data, about $60 \%$ of colleges have set up enterprise training bases, $30 \%$ of colleges have set up college-enterprise cooperation management departments, and $70 \%$ of colleges have set up enterprise practice bases. Overall, the colleges actively dock the actual needs of enterprises to achieve win-win cooperation with the enterprises. 


\section{The Informatization of Higher Education has been Greatly Improved}

Information platform is the main means for higher education and serve the society and students, and information resources are the foundation for higher education and serve the society and students. All the colleges actively accelerate the construction of digital resources, make efforts to increase the quantity of information digital resources, and actively build teaching websites and network platforms. The survey data shows that about $67 \%$ of colleges have actively carried out the construction of information digital resources, after development, they have built a large number of network courses, videos and other teaching resources, and have also formed special resources. For example, about $42 \%$ of colleges have set up information platforms to share resources; the colleges actively build network courses, shared courses and video courses with the help of Internet platform, and integrate education teaching, examination management and distance education policy, and provide multi-level and diversified educational services for all types of social members combining the informationization and quickness of knowledge economy. $32 \%$ of colleges have set up a perfect digital network teaching and management platform integrating teaching, management, service and scientific research to carry out network teaching and support services and monitor students' learning process and provide personalized service for students, possessing perfect supporting environment for teaching, learning and other informationization teaching. In view of the average input of colleges, the pilot colleges make a large investment in hardware investment, as they have constructed perfect hardware platforms and network frameworks, been equipped with adequate servers, routers and other network facilities, and built courseware broadcasting system and environment with good performance, laying a material foundation for the construction of network teaching resources.

Based on the analysis, it is observed that the higher education network teaching management platform and system of colleges are perfect, server and other hardware facilities are well established, the construction environment of teaching courseware and other digital resources are perfect, and the informatization level of network education is high. Especially the pilot colleges actively create characteristic network courses, actively explore and adapt to a variety of terminal learning needs as well as multiform and diversified new digital teaching resources such as "IMOOC class" and "micro class", and have built a number of digital learning resources with flexible forms, clearly content targeted and knowledge point as unit. For example, the pilot colleges have established 1,017 shared network courses of national resource, 227 shared network courses of a hundred of college resource alliance, and 209 state-level quality network courses, making useful exploration and positive contributions to the promotion of digital resource sharing and opening. The popularization of higher education informationization by the colleges promotes the innovation of educational concepts and teaching modes, and promotes the extensive application of information technology and network technology in the field of continuing education. The sample analysis shows that $11 \%$ of colleges make advantage of the information platform to improve their teaching quality by adopting various teaching modes.

\section{MAIN PROBLEMS IN CHINA'S HIGHER EDUCATION}

\section{The Positioning of Some Colleges is not Accurate}

Social development requires both research personnel and technical personnel. By training research personnel to improve management level, technical level and productivity level to promote economic and social development. By training technical personnel to train specialized technical personnel to transform knowledge technology into productivity. There is no doubt that these two kinds of education are important. However, in china it is generally believed that research-oriented higher education is more important than technology-oriented higher education, under the influence of this idea, the colleges focus on the training of research personnel instead of technical personnel, and some municipal colleges and private colleges' positioning of attaching importance to research instead of technology due to weak strength leads to decentralized teaching resources and low teaching quality. In fact, subordinate colleges and provincial colleges can attach importance to the training of research personnel, and municipal colleges and private colleges can attach importance to the training of technical personnel. At present, China's colleges do not have accurate positioning of their own development as their goal is just to build a comprehensive university. 


\section{The Education Scale Expands Too Fast}

Since 1999, China's colleges have begun to develop too fast as they are upgraded too much and too fast: technical secondary schools are upgraded to junior colleges, junior colleges are upgraded to undergraduate colleges, undergraduate colleges are upgraded to graduate colleges, and graduate colleges are upgraded to doctoral colleges, after a round of upgrading, colleges have expanded too fast. At the same time, the enrollment scale of colleges is increasing rapidly. By 2015, as the number of China's colleges reaches $36,470,000$, the scale of China's colleges has become the first in the world. This leads to a downward trend in college teachers' quality, standing in stark contrast to the surging growth of college students. The construction of college teachers cannot catch up with the growth of college students, so the overall education and teaching quality of higher education has been reduced. In the long run, the development of China's higher education is bound to be greatly affected.

According to survey data, $16.1 \%$ of colleges reflect that junior colleges and undergraduate colleges use the same training program and similar textbooks, which obviously does not accord with the basic teaching rules of higher education. Some colleges reflect that the colleges do not have the right to set up their own majors, which limits their ability to give full play to their academic and professional advantages and to serve the society. Moreover, all the colleges show low-level repeating major setting and strong homogenization, so they cannot meet the needs of the market. $67.9 \%$ of colleges believe that the current teaching material system and specialized curriculum system cannot meet the needs of application-oriented personnel training, so attention should be paid to the role of experimental teaching in the process of higher education. Furthermore, the construction of some specialized curriculum systems cannot meet the needs of personnel training by enterprises, as it cannot set up majors in response to enterprise requirements and is lack of practice and practical ability training; the teacher interaction mechanism and the system of "teacher entering the enterprise, the engineer entering the classroom" have not been established, and the practical skill training is lacked.

\section{The Funding of Some Colleges is Inadequate}

The fact that the tuition of China's colleges is low, pricing cycle is too long, and charging standard is single and lacks flexibility leads to colleges' failure to adapt to the needs of economic and social development for the higher education to serve the society. Some provincial colleges and municipal colleges don't increase their tuition for many years, leading to inadequate funding. Some private colleges don't have supporting funds as they are not financed by the state. The low tuition standard cannot maintain the necessary input in education and teaching, and seriously affect the construction of teachers, the reform of education and teaching as well as the improvement of education quality. Because of the low tuition standard, the students in some private college do not cherish the learning opportunity, and drop out of college randomly. Lack of financial input to private colleges leads to the fact that private higher education is often regarded as a profit-making activity, which affects the social reputation of private higher education.

\section{REGIONAL DIFFERENCES OF HIGHER EDUCATION IN CHINA}

\section{Regional Differences in the Number of Undergraduates per 10,000 Population}

The number of undergraduates per 10,000 population is an important indicator to measure education development in a region (Gao, 2017). Although the number of undergraduates in the total population of the country grows rapidly, but it varies widely across the country. The gap between eastern, central and western China is still very prominent. Taking the average number of undergraduates per one hundred thousand population in Chinese provinces in 2015 as an example, regional differences in higher education in different regions of China are analyzed, see Figure 1. 


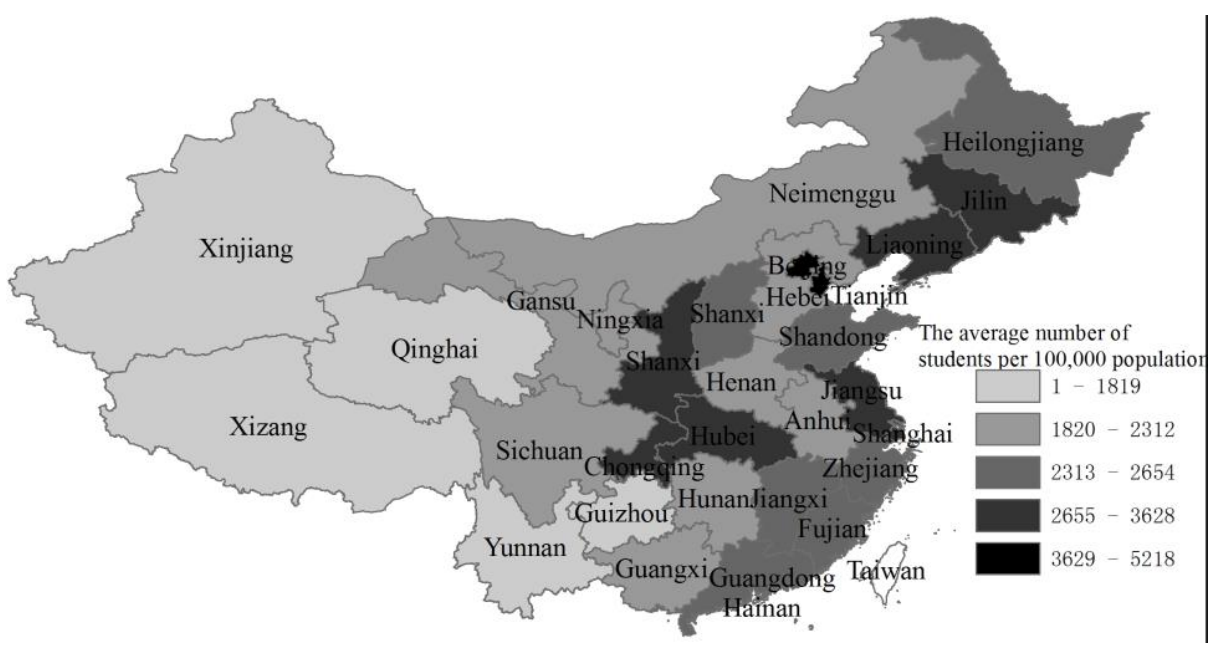

Figure 1. Regional differences in the number of undergraduates per 10,000 population

It can be seen from Figure 1 that the number of undergraduates in the east is greater than that in the west. The three provinces with the most number of undergraduates per one hundred thousand population are in the east. It is Beijing (5218 undergraduates) followed by Tianjin (4185 undergraduates) and Shanghai (3330 undergraduates). The three provinces with the least number of undergraduates per one hundred thousand population are in the west. It is Tibet (1766 undergraduates) followed by Yunnan (1819 undergraduates) and Guizhou (1819 undergraduates).

\section{Regional Differences of Contribution Rate of Higher Education to GDP Growth}

The model of the Cobb-Douglas production function is

$$
y=A K^{\alpha} L^{\beta}
$$

where $Y$ is the output, $A$ is the technical level, $K$ is the capital input level, $L$ is the labor input level, $\alpha$ is the coefficient of the capital output elasticity, $\beta$ is the coefficient of the labor output elasticity, $\alpha>0, \beta>0, \alpha+\beta=1$.

Based on Cobb-Douglas production function to calculate education contribution to GDP growth, namely measuring which national output growth rate in proportion to the GDP growth rate. Its theoretical basis is that education can improve labor productivity, and thus can affect labor inputs (Fan, 2017). In this paper, we use the product of base amount of labor input $L_{0}$ and education input $E$ to replace $L$. Take a logarithmic derivative of both sides of the production function, we get

$$
y=c+\alpha k+\beta l_{0}+\beta e
$$

where $y$ is the annual growth rate of the economy, $c, k, l_{0}$ and $e$ are and the annual growth rate of technological progress, capital, labor input and education respectively.

Therefore, the model of education's contribution to economic growth rate is:

$$
C_{E}=\frac{\beta e}{y}
$$

$\beta$ is different in different regions, and when study regions in China, scholars generally take between 0.7 and 0.8 . The $\beta$ in this model is 0.7 , i.e., $1 \%$ increase in labor input and $0.7 \%$ in output.

Defines education comprehensive index:

$$
e=\frac{\sum_{i=1}^{n} s_{i}}{n}
$$




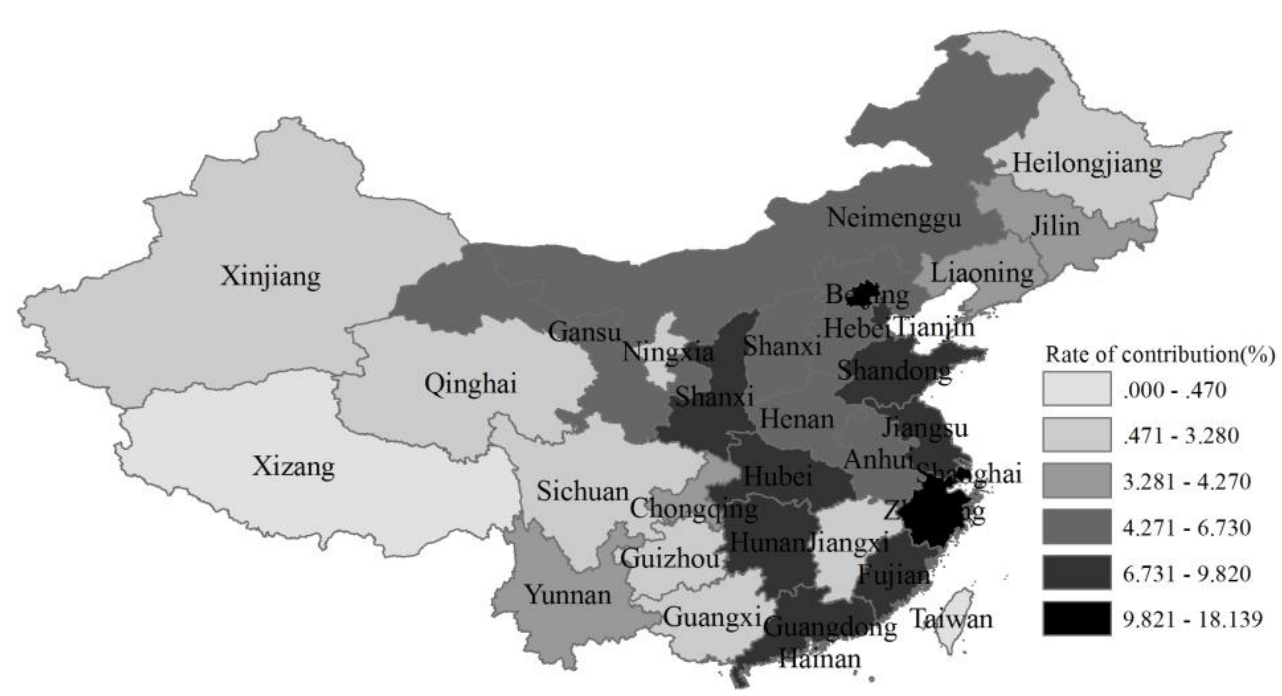

Figure 2. Regional differences of contribution rate of higher education to GDP growth

where $s_{i}$ is the education evaluation index, this paper uses the students in institutions of higher growth rate, growth rate of higher school faculty, institutions of higher learning funding growth rate to calculate. Taking the higher education statistical data in 2015 as an example, calculate regional GDP annual growth rate and growth rate of higher education, in order to calculate local higher education contribution to GDP growth, the calculation results as shown in Figure 2.

Can be seen from the Figure 2, eastern China, such as Beijing, Shanghai, Tianjin, Shandong and other regions, the contribution rate of higher education to economic growth is generally higher, western regions such as Xinjiang, Tibet, Qinghai and other regions, the contribution rate of higher education to economic growth is generally low.

\section{CONCLUSIONS AND SUGGESTIONS}

In this survey, we strongly feel that the time for advancing higher education reform has come. In the long run, we should expand the scale of higher education and meet the needs of the masses for higher education, more importantly, we should improve the quality of higher education and put the quality of higher education in a more prominent position. After all, the ultimate aim of colleges is to train more top-notch personnel, first-class personnel and innovative personnel. Based on this, the following countermeasures and suggestions were put forward in this paper.

Appropriately improve the tuition standard of higher education, pay attention to the training of teachers, and increase the remuneration of teachers to ensure the stability of teaching staff so as to ensure the quality of teaching. Further enrich the teaching resources of higher education, and constantly develop new teaching resources and courseware to provide students with high quality learning resources; meanwhile, increase the places, equipment and instruments for higher education teaching. In terms of teaching methods and means, it is recommended to adopt "expert lecture", "group discussion", "role play", "case teaching" and "field simulation" according to the characteristics and specific conditions of higher education, and combine the modern training with digital information technology, network technology, multimedia and other high-tech means to stimulate students' thirst for knowledge. In addition, the formulation of teaching plan and organization of teaching should be specific. Emphasize the practicability of teaching materials when choosing teaching materials, and encourage teachers to compile teaching materials by themselves according to their learning objects so as to better meet the requirements of students' thirst for knowledge. 
Further increase investment, improve the online learning platform of higher education, speed up the development and application of multimedia teaching courseware, and promote the construction of informatization of higher education by using distance education technology; develop high quality online courses and educational software; by effectively using modern scientific and technological means to build resource sharing platforms, and to establish relevant curriculum system, quality guarantee system, credit certification system and network education platform; give full play to the social service function of colleges. It is suggested that the colleges make full use of the advantages of disciplines to produce high-quality digital teaching resources and publish them via Internet platform to meet students' needs to learn anywhere and everywhere, thereby greatly easing the contradiction between work and study.

As for the regional differences of higher education in China, we should formulate a long-term plan to support the development of education in the western poverty-stricken areas, and set up the development of education in poverty-stricken areas fund. Besides, we should strengthen education counterpart support efforts, increase the investment of the central government, and mobilize all social forces to develop the education business in the Midwest.

\section{REFERENCES}

Chen, Z., Miller, P. A., Clements, T. L., \& Kim, M. (2017). Mapping Research in Landscape Architecture: Balancing Supply of Academic Knowledge and Demand of Professional Practice. Eurasia Journal of Mathematics Science and Technology Education, 13(7) 3653-3673. doi:10.12973/eurasia.2017.00751a

Ding, L., \& Zeng, Y. (2015). Evaluation of Chinese higher education by TOPSIS and IEW - The case of 68 universities belonging to the Ministry of Education in China. China Economic Review, 36, 341-358. doi:10.1016/j.chieco.2015.05.007

Ekici, D. I., (2017). The Effects of Online Communities of Practice on Pre-Service Teachers' Critical Thinking Dispositions. Eurasia Journal of Mathematics Science and Technology Education, 13(7), 3801-3827. doi:10.12973/eurasia.2017.00759a

Fan, X., \& Ma, S. (2017). Space-Time Characteristics Analysis of the Contribution of China's Higher Education to Economic Growth. China Higher Education Research, 8, 74-84. doi:10.16298/j.cnki.1004-3667.2017.08.15

Fang, W. (2012). The development of transnational higher education in China: A comparative study of research universities and teaching universities. Journal of Studies in International Education, 16(1), 5-23. doi:10.1177/1028315311410607.

Farhan, M., \& Aslam, M. (2017). An Interactive Assessment Framework for Visual Engagement: Statistical Analysis of a TEDx Video. Eurasia Journal of Mathematics Science and Technology Education, 13(4), 1107-1119. doi:10.12973/eurasia.2017.00661a

Feng, Y. (2013). University of Nottingham Ningbo China and Xi'an Jiaotong-Liverpool University: globalization of higher education in China. Higher Education, 65(4), 471-485. doi:10.1007/s10734-012-9558-8

Gao, W., Farahani, M. R., Aslam, A., \& Hosamani, S. (2017). Distance learning techniques for ontology similarity measuring and ontology mapping. Cluster Computing-The Journal of Networks Software Tools and Applications, 20(2SI) 959-968. doi:10.1007/s10586-017-0887-3

Gao, Y. Zhang, Y., \& Li, J. (2017). Research on the Spatial Spillover Effects of the Quantity of University on Economic Growth in China. China Higher Education Research, 8, 61-67. doi:10.16298/j.cnki.1004-3667.2017.08.13

Gupta, P., Mehrotra, D., \& Sharma, T. (2015). Identifying knowledge indicators in higher education organization. Procedia Computer Science, 46, 449-456. doi:10.1016/j.procs.2015.02.043

Hu, R. (2013). Report on China's education and human resources issues. Research in Educational Development, (Z1), 1. doi:10.14121/j.cnki.1008-3855.2003.z1.002

Huang, F. (2017).The impact of mass and universal higher education on curriculum and instruction: case studies of China and Japan. Higher Education, 74(3), 507-525. doi:10.1007/s10734-016-0061-5

Liu, L., Yao, H., \& Wen, A. (2016). Study on the adaptive evaluation of education structure in various provinces and autonomous regions of China. Research in Educational Development, 36(17), 17-21. doi:10.14121/j.cnki.1008-3855.2016.17.005 
Mok, K. H., \& Wu, A. (2016). Higher education, changing labor market and social mobility in the era of massification in China. Journal of Education and Work, 29(1), 77-97. doi:10.1080/13639080.2015.1049028

Opitz, S. T., Neumann, K., Bernholt, S., \& Harms, U. (2017) How Do Students Understand Energy in Biology, Chemistry, and Physics? Development and validation of an assessment instrument. Eurasia Journal of Mathematics Science and Technology Education, 13(7), 3019-3042. doi:10.12973/eurasia.2017.00703a

\section{http://www.ejmste.com}

